Egyptian Journal of Aquatic Biology \& Fisheries

Zoology Department, Faculty of Science,

Ain Shams University, Cairo, Egypt.

ISSN $1110-6131$

Vol. 23(2): 265 - 274 (2019)

www.ejabf.journals.ekb.eg

\title{
Antibacterial activity of some seaweeds from the Red Sea coast of Egypt.
}

\author{
Fedekar Fadel Madkour $^{1 *}$, Gihan Ahmed El-Shoubaky ${ }^{2}$ \\ and Mohamed Attia Ebada ${ }^{1}$
}

1- Marine Science Department, Faculty of Science, Port Said University, Port Said, Egypt.

2- Botany Department, Faculty of Science, Suez Canal University, Ismailia, Egypt.

*Corresponding author: fedekarmadkour@ymail.com

\section{ARTICLE INFO \\ Article History: \\ Received: March 11, 2019 \\ Accepted: April 27, 2019 \\ Online: May 2019}

Keywords:

Seaweed

antibacterial activity

Red Sea

pathogenic bacteria

Phaeophyta

\begin{abstract}
Some commonly occurring brown algae Turbinaria ornata, Cystosiera myrica and Padina pavonica have been collected from the Red Sea coast of Egypt. Three different solvents namely acetone, isopropyl alcohol and ethanol were used for preparing crude algal extracts. The antibacterial activities of crude extracts were evaluated against three pathogens: Grampositive bacteria (Staphylococcus aureus) and Gram-negative bacteria (Pseudomonas aeruginosa and Escherichia coli) by disc diffusion method, and then inhibition zones were compared. Strong antibacterial activity was observed for $T$. ornata, giving high potent with isopropyl alcohol against $S$. aureus and E. coli, with acetone against $P$. aeruginosa and with ethyl alcohol against $S$. aureus (inhibition zone $>14 \mathrm{~mm}$ ). Extracts of $P$. pavonica and C. myrica showed lower antibacterial activity zones, with no inhibition for most tested trials. Among solvents, isopropyl alcohol showed the highest inhibitory action, followed by acetone with moderate antimicrobial activity while ethanol revealed low antibacterial activity, giving inhibitory action only against Gram positive bacteria (S. aureus). Gram positive bacteria were more susceptible to the algal extracts than Gram negative bacteria. The present study revealed that $T$. ornata is a promising alga to act as an antimicrobial agent in food products, pharmacology and medical applications.
\end{abstract}

\section{INTRODUCTION}

Pathogenic bacteria is one of the most nuisance organisms because it causes many serious diseases for human and animals. Of the pathogenic bacteria for instance, Escherichia coli, Staphylococcus aureus and Pseudomonas aeruginosa cause diseases like mastitis, abortion and upper respiratory complications (Jawetz et al., 1995). P. aeruginosa is a prevalent pathogen among burned patients capable of causing life-threatening illness (Kandhasamy and Arunachalam, 2008). Recently, the use of antimicrobial drugs has a great challenge due to their side effects and changing strategy of resistance in pathogens. Therefore, there is a need for continuous searching for new antimicrobial compounds to develop more effective and safe drugs. Accordingly, pharmaceutical industries are giving importance to the compounds derived from traditional sources (Solomon and Santhi, 2008). 
Traditional and modern medicines have relatively exhausted most of their resources in land plants. Nowadays, the marine environment is considered a rich source of new agents used in medicine (Bazes et al., 2006; Chew et al., 2007; Mayer et al., 2007). Recently, numerous novel compounds have been isolated from marine organisms and many of these substances have been demonstrated to possess interesting biological activities (Duarte et al., 2002; Faulkner, 2002; Ely et al., 2004; Dubber and Harder, 2008).

Actually, seaweeds are the most interesting marine organisms that traditionally used in human and animal nutrition (Dawczynski et al., 2007). Also, they are known to produce structurally diverse and biologically active secondary metabolites which act as defense mechanism against fouling organisms and herbivores (Bhadury and Wright, 2004). Most bioactive compounds obtained from seaweeds are used in pharmaceutical industries, such as antimicrobial, antiviral, antifungal, anticancer and antioxidant activities (Shanab 2007; Kolanjinathan et al. 2014; Lavanya et al. 2017).

The algal richness of Egyptian Red Sea coasts is undeniable in terms of diversity and quantity (Chiffings, 2003). The antimicrobial potential of seaweeds from Red Sea coasts of Egypt (Shanab 2007; Salem et al. 2011; El-Sheekh et al. 2014) and of Saudi Arabia (Omar et al. 2012; Al-Saif et al. 2014; Moubayed et al. 2017) remains partially unexplored.

The present study was undertaken to examine the antibacterial effect of crude extracts of three species of brown seaweeds, Turbinaria ornata, Cystosiera myrica and Padina pavonica, collected from the Egyptian Red Sea coasts, against pathogenic bacteria Escherichia coli, Staphylococcus aureus and Pseudomonas aeruginosa. Also, the efficacy of the three solvents, acetone, isopropyl alcohol and ethanol to obtain the most effective crude extract from each seaweed was evaluated.

\section{MATERIALS AND METHODS}

\section{Algal materials}

Samples of three species of algae belong to the Phaeophyta; Turbinaria ornata (Turner) J.Agardh, Cystosiera myrica (S.G.Gmelin) C.Agardh, and Padina pavonica (Linnaeus) Thivy (Fig. 1), were collected from Egyptian Red Sea at Wadi El Gemal National Park. The algae were identified according to Aleem $(1978,1981)$ and Abbott and Hollenberg (1976).

Turbinaria ornata

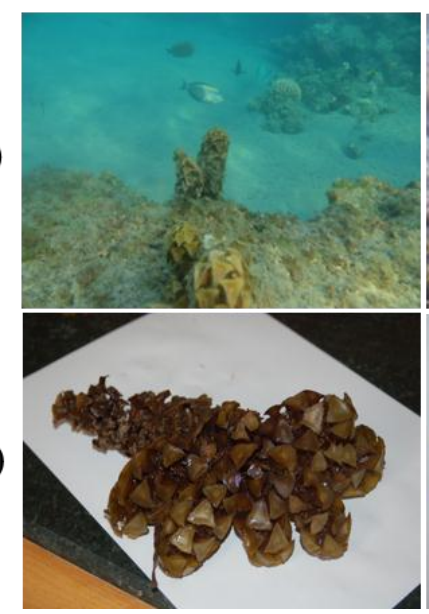

Cystoseira myrica

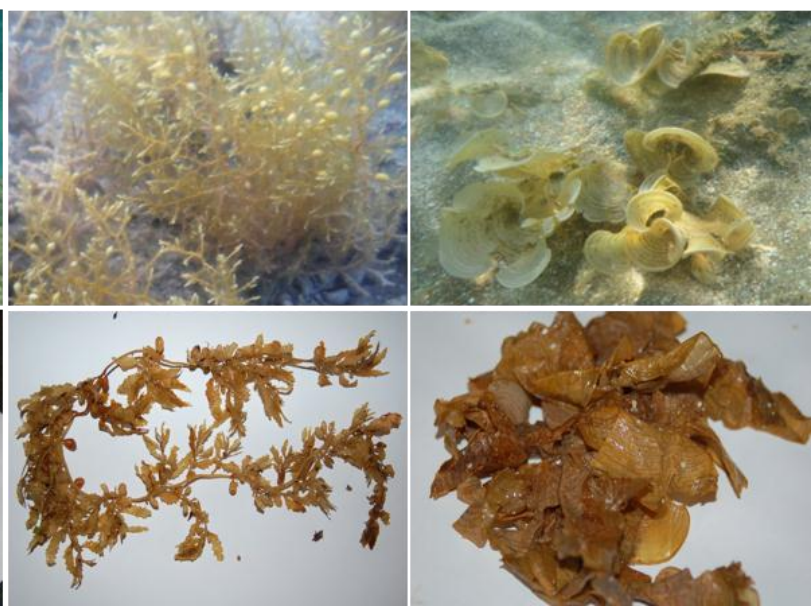

Fig. 1: The three tested algal species at a) collected location under water, and b) the laboratory after washing. 
Algal materials were cleaned with seawater to remove all the extraneous matter such as epiphytes, and non-living matrixes and brought to the laboratory in plastic bags. The samples were thoroughly washed with freshwater, and rinsed many times in distilled water, then spread out at room temperature for drying. Shade dried seaweed materials were ground into powder in an electrical mill. The powdered samples were stored in the dark bottles at room temperature for further use.

\section{Algal extract}

The algal extract was prepared by soaking the algal powder in different solvents (acetone, isopropyl and methyl alcohols) in a conical flask (50 g dry algae/1000 $\mathrm{ml}$ solvent) for two days. The final extract was filtered by Whatman filter paper and the filtrate was concentrated in a rotary evaporator at room temperature $\left(30^{\circ} \mathrm{C}\right)$ and the crude extract kept deep frozen for further assays.

\section{Test microorganisms}

The antimicrobial activity of acetone, isopropyl and methyl alcohols of marine algal extracts were examined in vitro against selected human pathogens such as Gram-positive bacteria (Staphylococcus aureus) and Gram-negative bacteria (Pseudomonas aeruginosa and Escherichia coli). The microorganisms used in this study were obtained from microbiology laboratory at Suez Canal University Hospital. The pathogenic bacteria were grown on nutrient agar medium, which was sterilized, and $25 \mathrm{ml}$ was poured into sterile cabbed test tubes. Test tubes were cooled to room temperature and $0.5 \mathrm{ml}$ of the uniform mixture of inoculum was introduced to each tube then well mixed. The content of each tube was poured into a sterile Petri-dish for solidification (Mtolera and Semesi, 1996).

\section{Antibacterial assay}

The antimicrobial activity was carried out using disc diffusion method (Tendencia, 2004). Paper disc of $6 \mathrm{~mm}$ in diameter prepared from Whatman filter paper was soaked with the crude extract and placed onto the bacterial lawn after it had solidified and incubated at $37^{\circ} \mathrm{C}$ for $24 \mathrm{~h}$. After incubation, a clear zone was observed around paper disc and the diameter of the inhibition zone measured in millimeters. All assays were done in four replicates and data were expressed as mean values $\pm \mathrm{SD}$.

\section{RESULTS}

Different extracts of T. ornata, C. myrica and P. pavonica were tested for their antimicrobial activity against three strains of microorganisms by disc diffusion method. However, the results of antimicrobial activity against tested pathogens are presented in Table (1) and Figures (2-4).

Table 1: Inhibition zone $(\mathrm{mm})$ of different crude extracts of three species of seaweed extracts against selected pathogenic bacteria.

\begin{tabular}{|c|c|c|c|c|c|c|c|c|c|}
\hline \multirow{2}{*}{$\begin{array}{l}\text { Tested } \\
\text { bacteria }\end{array}$} & \multicolumn{3}{|c|}{ Turbinaria ornata } & \multicolumn{3}{|c|}{ Cystoseira myrica } & \multicolumn{3}{|c|}{ Padina pavonica } \\
\hline & Acetone & $\begin{array}{l}\text { Isopropyl } \\
\text { alcohol }\end{array}$ & $\begin{array}{c}\text { Ethyl } \\
\text { alcohol }\end{array}$ & Acetone & $\begin{array}{c}\text { Isopropyl } \\
\text { alcohol }\end{array}$ & $\begin{array}{c}\text { Ethyl } \\
\text { alcohol }\end{array}$ & $\begin{array}{c}\text { Aceton } \\
\mathrm{e}\end{array}$ & $\begin{array}{c}\text { Isopropyl } \\
\text { alcohol }\end{array}$ & $\begin{array}{c}\text { Ethyl } \\
\text { alcohol }\end{array}$ \\
\hline P. aeruginosa & $14.5 \pm 1.7$ & $3.5 \pm 1.92$ & Nil & $2.75 \pm 0.5$ & $15.5 \pm 0.57$ & Nil & Nil & Nil & Nil \\
\hline S. aureus & $5.25 \pm 0.95$ & $15 \pm 1.4$ & $14 \pm 1.15$ & Nil & $4 \pm 0.81$ & $\begin{array}{c}4.25 \pm 0 \\
5\end{array}$ & $15 \pm 0.7$ & $4.5 \pm 1.2$ & $3.29 \pm 5$ \\
\hline E. coli & $1.75 \pm 0.5$ & $14.75 \pm 1.3$ & $0.25 \pm 0.5$ & Nil & Nil & Nil & $2 \pm 0.2$ & $4.5 \pm 1.1$ & Nil \\
\hline
\end{tabular}


The inhibition zones observed by different extracts of $T$. ornata against the pathogenic bacteria are represented in Figure (2). Turbinaria ornata showed high antibacterial activity with isopropyl alcohol extract against $S$. aureus and E. coli, with acetone extract against $P$. aeruginosa and with ethyl alcohol extract against $S$. aureus (inhibition zone $>14 \mathrm{~mm}$ ). On the other hand, ethyl alcohol extract of $T$. ornata had no effect on $P$. aeruginosa. Otherwise, low to moderate activity was observed for different solvents against the pathogenic bacteria.
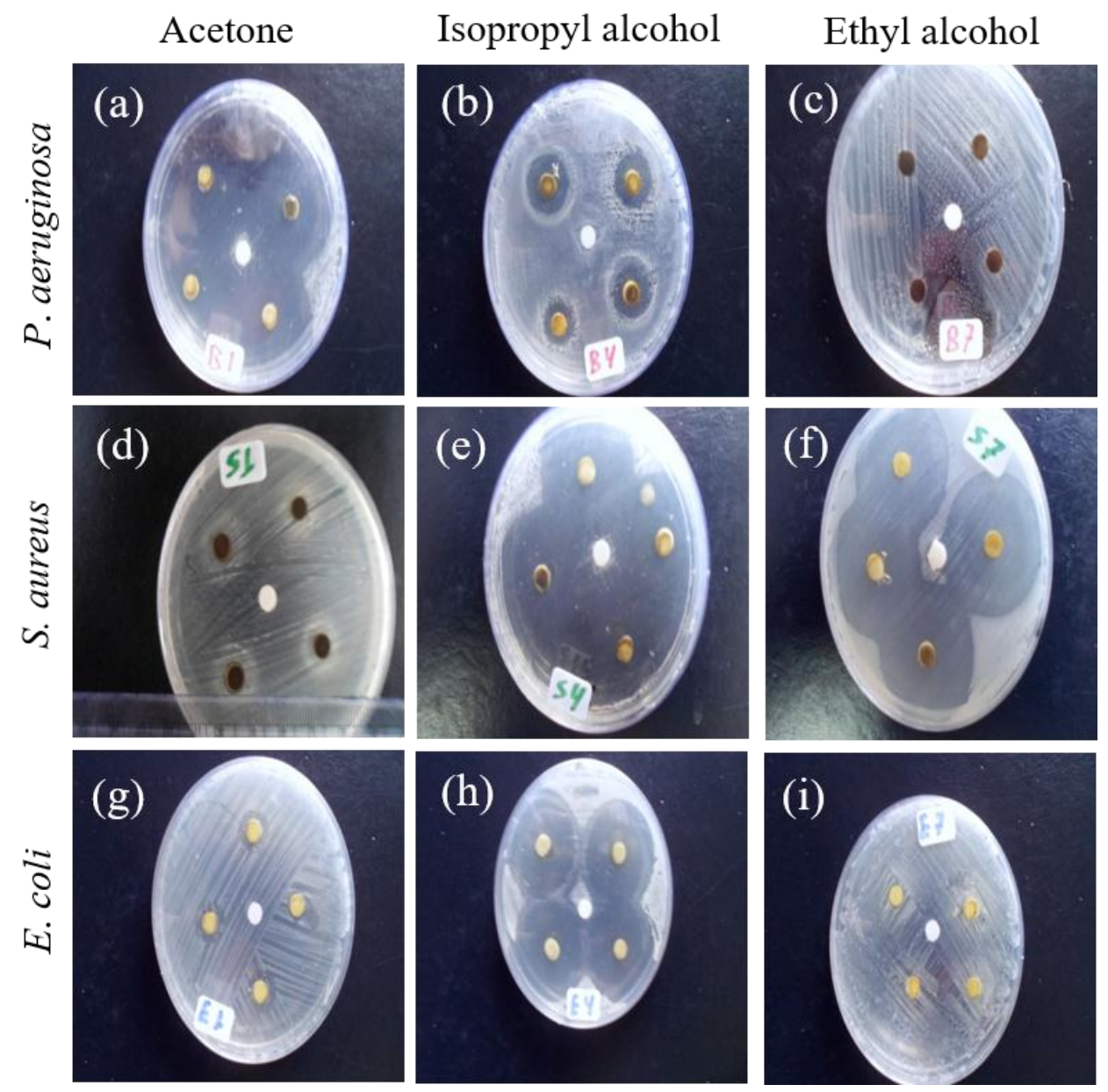

Fig. 2: Inhibition zone (mm) of different crude extracts of $T$. ornata against $P$. aeruginosa (a, b, c), $S$. aureus (d, e, f) and E. coli $(\mathrm{g}, \mathrm{h}, \mathrm{i})$.

Cystosiera myrica showed either low antibacterial activity (inhibition zone $<4$ $\mathrm{mm}$ ) or no inhibition zone for all solvents against all tested bacteria except for isopropyl alcohol extract against $P$. aeruginosa (inhibition zone: $15.5 \pm 0.57 \mathrm{~mm}$ ). The extracts of $C$. myrica with all solvents used in the present study did not give any inhibition zone against $E$. coli (Figure 3). Isopropyl alcohol extract of $C$. myrica showed a broad inhibitory activity, giving the highest activity against $P$. aeruginosa (inhibition zone: $15.5 \pm 0.57 \mathrm{~mm}$ ), moderate activity against $S$. aureus (inhibition zone: $4 \pm 0.81 \mathrm{~mm}$ ) and without activity against $E$. coli.

No extracts of $P$. pavonica affected the Gram negative bacteria $P$. aeruginosa (Figure 4). Staphylococcus aureus was the most sensitive bacteria for $P$. pavonica extracts, especially acetone extract (inhibition zone: $15 \pm 0.7 \mathrm{~mm}$ ), while isopropyl and ethyl alcohols extracts showed low activity (inhibition zone: $4.5 \pm 1.2$ and $3.29 \pm 0.5 \mathrm{~mm}$, respectively). Acetone and isopropyl alcohol extracts of $P$. pavonica 
showed low activity against $E$. coli (inhibition zone: $2 \pm 0.2$ and $4.5 \pm 1.1 \mathrm{~mm}$, respectively), while ethyl alcohol extract did not affect it.

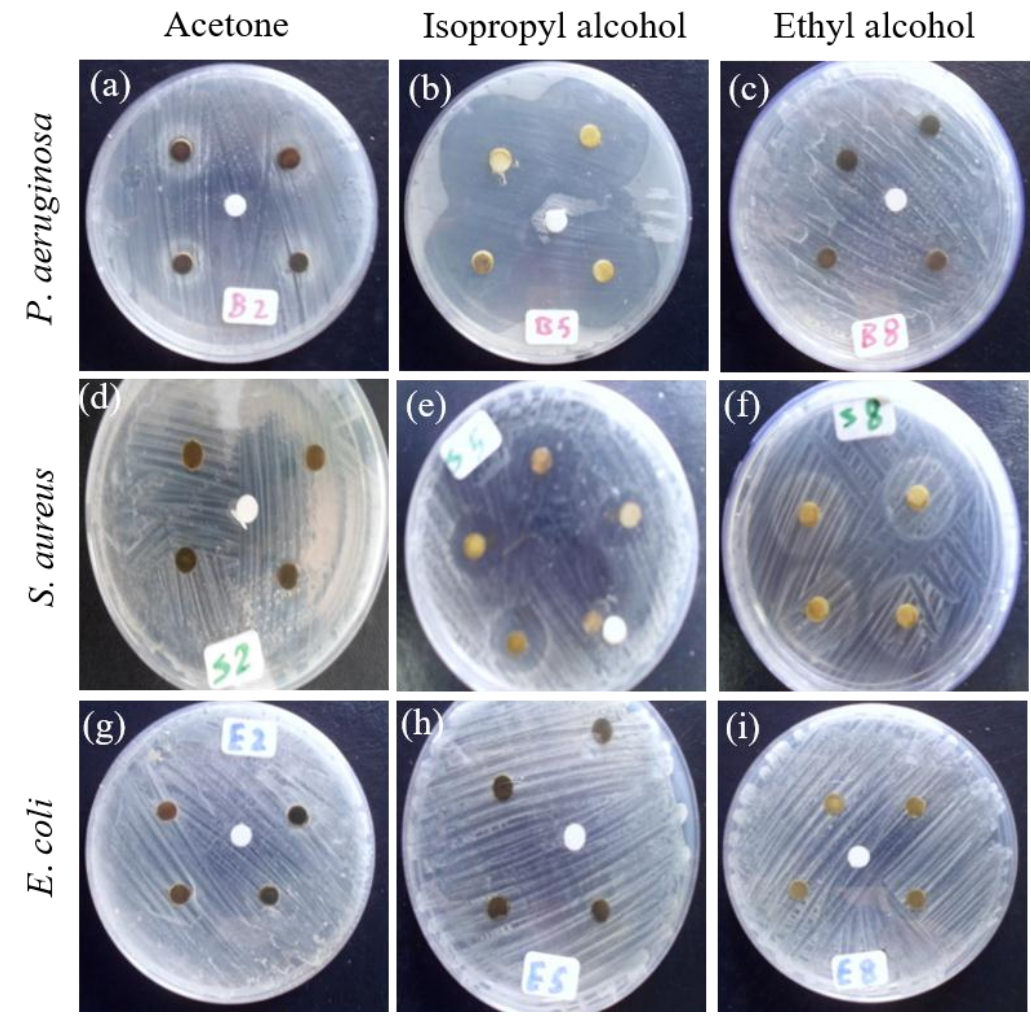

Fig. 3: Inhibition zone (mm) of different crude extracts of $C$. myrica against $P$. aeruginosa (a, b, c), $S$. aureus (d, e, f) and E. coli $(\mathrm{g}, \mathrm{h}, \mathrm{i})$.
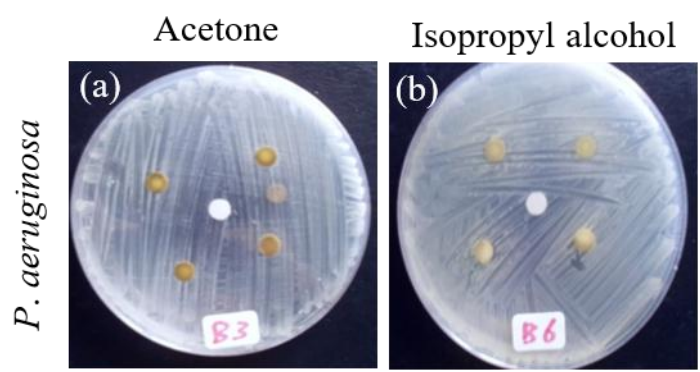

Ethyl alcohol
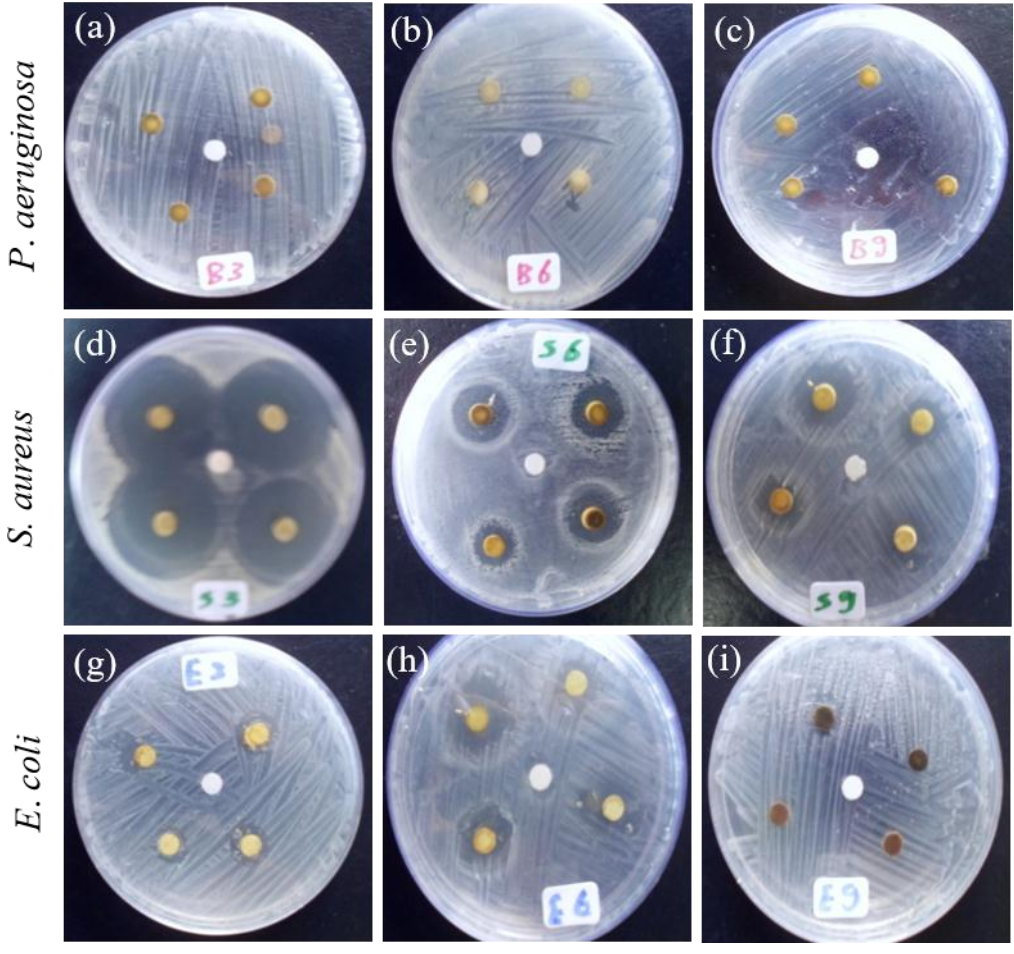

Fig. 4: Inhibition zone (mm) of different crude extracts of $P$. pavonica against $P$. aeruginosa (a, b, c), S. aureus (d, e, f) and E. coli (g, h, i). 


\section{DISCUSSION}

Seaweeds act as potential bioactive compounds for pharmaceutical applications. This capability of seaweeds can be attributed to synthesis of various bioactive secondary metabolites which are biologically active against different types of pathogenic bacteria (Kolanjinathan et al. 2014; Abdel-Latif et al. 2018). The majority of the compounds isolated from marine algae that responsible for the antimicrobial activity are lipids (Rosell and Srivastava, 1987).

In the present study, the crude extracts of the three selected species of brown algae showed antibacterial activities against tested bacteria with various inhibitory actions depending on the seaweed species and the solvent used. Strong antibacterial activity was observed for $T$. ornata in all extracts with high potent against all tested bacteria. T. ornata demonstrated a broad spectrum of microbial growth inhibition for both Gram positive and Gram negative bacteria. Rajkumar (2017) stated that methanolic extract of $T$. ornata was worked well against $P$. aeruginosa and produced $24.02 \pm 0.47 \mathrm{~mm}$ zone of inhibition. Vijayabaskar and Shiyamala (2011) tested the methanol extracts of brown algae Sargassum wightii and Turbinaria ornata against various Gram positive and Gram negative human pathogenic microbes. Their finding envisages that methanol extracts of $T$. ornata could be utilized as a good source of antimicrobial agent in pharmaceutical industry.

Cystosiera myrica and $P$. pavonica showed lower antibacterial activities, especially against Gram negative bacteria ( $P$. aeruginosa and E. coli). Salem et al. (2011) found that Enterococcus feacalis was resistant to methanolic and ethyl acetate extracts of $C$. myrica. Our results also accords with the findings of El-Shoubaky and Salem (2014) who evaluated the potential antimicrobial activity of Padina pavonica collected from Red Sea of Saudi Arabia and their fatty acids content. They found that fatty acids extract of $P$. pavonica showed no inhibition effect against $E$. coli and $S$. aureus. The differential antibacterial activities of these marine algae may be attributed to the presence of different antibacterial active compounds which are easily extracted with organic solvents.

The highest inhibitory action among all extracts was obtained with isopropyl alcohol extract. Although isopropyl alcohol is known as a solvent for a wide range of non-polar compounds compared to other organic solvents (e.g. methanol), it was not seemed as a preferable solvent in the studies dealing with antimicrobial activities of algal extracts. The finding of the present study suggests that the isopropyl alcohol crude extracts of brown algae could be contained a new antibacterial compound(s) showed high activity against human pathogenic bacteria and further studies are required to purify the active principles.

Moderate antimicrobial activity was obtained with acetone extracts. Earlier studies on antibacterial screening using various solvent extracts revealed that the crude acetone extracts of different seaweeds reacted positively against selected human bacterial pathogens (Oumaskour et al., 2012, Venugopal et al., 2014; Moorthi and Balasubramanian, 2015; Rosaline et al., 2017; Qari and Khan, 2019).

On the other hand, ethanol extracts revealed meager antibacterial activity, giving inhibitory action only against Gram positive bacteria (S. aureus). Ambreen $e t$ al. (2012) screened ethanol extract of 5 seaweeds for antibacterial activity, and 9 tested against root rotting fungi and found that the ethanol extract of most of the species was less active against tested fungi.

The study confirmed that susceptibility of Gram positive bacteria (S. aureus) to the algal extracts was more than those of Gram negative bacteria $(P$. aeruginosa and 
E. coli). A similar observation was recorded by Salem et al. (2011) who found that Gram negative bacteria (E. coli, P. aeruginosa, Enterococcus feacalis and Salmonella sp.) were the most resistant bacteria to most tested seaweed extracts while Gram positive bacteria ( $S$. aureus and Bacillus cereus) were the most sensitive to all seaweed extracts. In the same context, Oumaskour et al. (2012) and Al-Haj et al. (2009) reported that the Gram-positive bacteria presented a sensibility superior to the Gram-negative. Moreover, $S$. aureus was observed to be the most sensitive bacteria to most algal extracts (Oumaskour et al., 2012; Belattmania et al., 2016). This may be due to the more complex structure and composition of Gram negative bacterial cell wall (Rosell and Srivastava, 1987). Mendes et al. (2013) showed that the outer membrane and the thick murein layer of Gram negative bacteria act as a barrier, preventing the entrance of environmental substances such as antibiotics and inhibitors.

\section{CONCLUSION}

Conclusively, the current study showed appreciable antibiotic activity by all the three algae $T$. ornata, $C$. myrica and $P$. pavonica against certain human pathogens. These three species of algae that grow excessively at Wadi El Gemal National Park coast in Red Sea, Egypt can be used for development of anti-pathogenic drugs in the pharmaceutical industries. The present study revealed that $T$. ornata is a promising alga, as there may be a potential to utilize its extract in food products to act as antimicrobial agent, which could potentially increase the shelf life and safety of a wide range of food products, or in pharmacology as new agent for therapeutic medical and veterinary applications. However a detailed study in this field is required for isolation and characterization of the antibacterial compounds from these marine macro-algae.

\section{REFERENCES}

Abdel-Latif, H.H.; Shams El-Din, N.G. and Ibrahim, H.A.H. (2018). Antimicrobial activity of the newly recorded red alga Grateloupia doryphora collected from the Eastern Harbor, Alexandria, Egypt. J. Appl. Microbiol., 125: 1321-1332.

Abbott, L.A. and Hollenberg, L.G. (1976). Marine Algae of California Stanford. University Press, Stanford, California, USA.

Aleem, A.A. (1978). Contributions to the study of the marine algae of the Red Sea. III- Marine algae from Obhor, in the vicinity of Jeddah, Saudi Arabia. Bull. Fac. Sci. KAUJ. 2: 99-118.

Aleem, A.A. (1981). Contributions to the study of the marine algae of the Red Sea. New or little known algae from the west coast of Saudi Arabia. Bull. Fac. Sci. KAUJ. 5: 1-49.

Al-Haj, N.A.; Mashan, N.I.; Shamsudin, M.N.; Mohamad, H.; Vairappan, C.S. and Sekawi, Z. (2009). Antibacterial activity in marine algae Eucheuma denticulatum against Staphylococcus aureus and Streptococcus pyogenes. Research Journal of Biological Sciences, 4: 519-524.

Al-Saif, S.S.; Abdel-Raouf, N.; El-Wazanani, H.A. and Aref, I.A. (2014). Antibacterial substances from marine algae isolated from Jeddah coast of Red sea, Saudi Arabia. Saudi J. Biol. Sci., 21(1): 57-64. 
Ambreen, H.K.; Tariq, A.; Ruqqia, Sultana, V. and Ara, J. (2012). Antimicrobial activity of some seaweeds occurring at Charachi coast. Pak. J. Bot., 44(5): 1799-1803.

Bazes, A.; Silkina, A.; Defer, D.; Bernede-Bauduin, C.; Quemener, E.; Braus, J.P. and Bourgougnon, N. (2006). Active substances from Ceramium botryocarpum used as antifouling products in aquaculture. Aquaculture, 258: 664-674.

Belattmania, Z.; Engelen, A.H.; Pereira, H.; Serrão, E.A.; Barakate, M.; Elatouani, S.; Zrid, R.; Bentiss, F.; Chahboun, N.; Reani, A. and Sabour, B. (2016). Potential uses of the brown seaweed Cystoseira humilis biomass: 2-Fatty acid composition, antioxidant and antibacterial activities. J. Mater. Environ. Sci., 7(6): 2074-2081.

Bhadury, P.1. and Wright, P.C. (2004). Exploitation of marine algae: biogenic compounds for potential antifouling applications. Planta, 219(4): 561-78.

Chew, Y.L.; Lim, Y.Y.; Omar, M. and Khoo, K.S. (2007). Antioxidant activity of three edible seaweeds from two areas in south East Asia. Food Science and Technology, 41: 1067-1072.

Chiffings, T. (2003). Marine region 11: Arabia seas, a global representative system of marine protected areas.

Dawczynski, C.H.; Schubert, R. and Jahreis, G. (2007). Amino acids, fatty acids, and dietary fibre in edible seaweed products. Food Chem., 103: 891-899.

Duarte, M.E.R.; Noseda, D.G.; Noseda, M.D.; Tulio, S; Pujol, C.A. and Damonte, E.B. (2002). Inhibitory effect of sulfated galactans from the marine alga Bostrychia montagnei on herpes simplex virus replication in vitro. Phytomedicine, 8: 53-58.

Dubber, D. and Harder, T. (2008). Extracts of Ceramium rubrum, Mastocarpus stellatus and Laminaria digitata inhibit growth of marine and fish pathogenic bacteria at ecologically realistic concentrations. Aquaculture, 274: 196-200.

El-Sheekh, M.M.; Gharieb, M.M.; El-Sabbagh, S.M. and Hamza, W.T. (2014). Antimicrobial efficacy of some marine macroalgae of Red Sea. International Journal of Microbiology and Immunology Research, 3(3): 21-28.

El Shoubaky, G.A. and Salem E.A.E. (2014). Active ingredients fatty acids as antibacterial agent from the brown algae Padina pavonica and Hormophysa triquetra. Journal of Coastal Life Medicine, 2(6): 431-438.

Ely, R.; Supriya, T. and Naik, C.G. (2004). Antimicrobial activity of marine organisms collected off the coast of south east India. Journal of Experimental Marine Biology and Ecology, 309: 121-127.

Faulkner, D.J. (2002). Marine natural products. Natural Product Reports, 19: 1-48.

Jawetz, E.; Mellnick, J.L. and Adelberg, E.A. (1995). Review of Medical Microbiology. 20th Edition. Applellation Lange Norwalk, Connecticut, pp. 139-218.

Kandhasamy, M. and Arunachalam, K.D. (2008). Evaluation of in vitro antibacterial property of seaweeds of southeast coast of India. Afr. J. Biotechnol., 7(12): 1958-1961.

Kolanjinathan, K.; Ganesh, P. and Saranraj, P. (2014). Pharmacological importance of seaweeds: A review. World Journal of Fish and Marine Sciences, 6(1): 1-15.

Lavanya, M.; Thangamathi, P.; Ananth. S. and Gnanasoundari, A. (2017). Properties of seaweeds. A review. International Journal of Current Innovation Research, 3(10): 843-846.

Mayer, A.M.S.; Rodriguez, A.D.; Berlinck, R.G.S. and Hamann, M.T. (2007). Marine pharmacology in 2003-4: Marine compounds with anthelmintic 
antibacterial, anticoagulant, antifungal, anti-inflammatory, antimalarial, antiplatelet, antiprotozoal, antituberculosis, and antiviral activities; affecting the cardiovascular, immune and nervous systems, and other miscellaneous mechanisms of action. Comparative Biochemistry and Physiology, 145: 553581.

Mendes, M.; Pereira, R.; Sousa Pinto, I.; Carvalho, A.P. and Gomes, A.M. (2013). Antimicrobial activity and lipid profile of seaweed extracts from the North Portuguese Coast. Int. Food Res. J.; 20(6): 3337-3345.

Moorthi, P.V. and Balasubramanian, C. (2015). Antimicrobial properties of marine seaweed, Sargassum muticum against human pathogens. Journal of Coastal Life Medicine, 3(2): 122-125.

Moubayed, N.M.S.; Al Houri, H.J.; Al Khulaifi, M.M. and Al Farraj, D.A. (2017). Antimicrobial, antioxidant properties and chemical composition of seaweeds collected from Saudi Arabia (Red Sea and Arabian Gulf). Saudi J. Biol. Sci., 24(1): 162-169.

Mtolera, M.S. and Semesi, A.K. (1996). Antimicrobial activity of extracts from six green algae from Tanzania. Curr. Trends Mar. Bot. East Afr. Reg., 211-217.

Omar, H.H.; Shiekh, H.M.; Gumgumjee, N.M.; El-Kazan, M.M. and El-Gendy, A.M. (2012). Antibacterial activity of extracts of marine algae from the Red Sea of Jeddah, Saudi Arabia. African Journal of Biotechnology, 11(71): 13576-13585.

Oumaskour, K.; Boujaber, N.; Etahiri, S. and Assobhei, O. (2012). Screening of antibacterial and antifungal activities in green and brown algae from the coast of Sidi Bouzid (El Jadida, Morocco). African Journal of Biotechnology, 11:16831-16837.

Qari, R. and Khan, A. (2019). Studies on antibacterial activity and phytochemical analysis of Gracilaria corticata (J. Agardh), Gracilaria dentata (J. Agardh) and Gracilaria pygmaea (Børgesen) against diarrheal causing pathogen E. coli and Salmonella typhi. Acta Scientific Microbiology, 2(3): 3-11.

Rajkumar, G.; Bhavan, P.S.; Srinivasan, V.; Asaikutti, A. and Udayasuriyan, R. (2017). In vitro and in vivo antibacterial activity of marine alga Turbinaria ornata against Pseudomonas aeruginosa in the freshwater prawn Macrobrachium rosenbergii. JSM Biotechnol. Bioeng., 4(2): 1-8.

Rosaline, X.D.; Sakthivelkumar, S.; Chitra, S. and Janarthanan, S. (2017). Antibacterial activity of the seaweeds Chaetomorpha linum and Padina gymnospora on human bacterial pathogens. Journal of Environment and Biotechnology Research, 6(1): 43-52.

Rosell, K.G. and Srivastava, L.M. (1987). Fatty acids as antimicrobial substances in brown algae. Hydrobiologia, 151-152: 471-475.

Salem, W.M.; Galal, H. and Nasr El-deen, F. (2011). Screening for antibacterial activities in some marine algae from the Red Sea (Hurghada, Egypt). African Journal of Microbiology Research, 5: 2160-2167.

Shanab, S.M.M. (2007). Antioxidant and antibiotic activities of some seaweeds (Egyptian isolates). International Journal of Agriculture and Biology, 9(2): 220225.

Solomon, R.D.J. and Santhi, V.S. (2008). Purification of bioactive natural product against human microbial pathogens from marine seaweed Dictyota acutiloba. J. Ag. World J. Microbiol. Biotechnol., 24: 1747-1752.

Tendencia, E.A. (2004). Disk diffusion method. In Laboratory manual of standardized methods for antimicrobial sensitivity tests for bacteria isolated from aquatic animals and environment (pp. 13-29). Tigbauan, Iloilo, 
Philippines: Aquaculture Department, Southeast Asian Fisheries Development Center.

Venugopal, A.K.B.; Thirumalairaj, V.K.; Durairaj, G.; Vijayan, M.P.; Lazar Sathyan, K.K.; Chacko, A.; Yesudas, R.; Kadheeja, S.; David, I.K.J. and Damascene, S.J. (2014). Microbicidal activity of crude extracts from Sargassum wightii against Bacillus cereus. International Current Pharmaceutical Journal, 3(10): 326-327.

Vijayabaskar, P. and Shiyamala, V. (2011). Antibacterial activities of brown marine algae (Sarggassum wightii and Turbinaria ornate) from the Gulf of Manner. Biosphere Reserve Advances in Biological Research, 5(2): 99-102. 